\title{
Cognitive Level Profile in Solving Mathematics Problem at Ten Grade of Senior High School Students with Low Ability
}

\author{
Khisna Yumniyati; Imam Sujadi; Diari Indriati \\ Sebelas Maret University, Indonesia \\ Email: khisnayumniyati@gmail.com
}

http://dx.doi.org/10.18415/ijmmu.v6i1.485

\begin{abstract}
This research is motivated by the importance of problem solving skill for students in 21st century, whereas students' skill in solving mathematics problems is various in accordance their cognitive levels. Students' cognitive levels in solving problems include;cognition; metacognition; and epistemic cognition. Cognitive level affects individual in understanding problem and deciding the right strategy to solve it. The purpose of this study is to describe cognitive levels of low-ability students. This study uses qualitative methods with task-based interviews. The material is three-variable linear equation system. The research subjects are two low-ability students at ten grade of State Senior High School in Pati Regency. The results show that the two subjects have weaknesses at each level, for example the two subjects are able to work on the given problems, but both subjects are unable to define equations, inequality, similarity, and dissimilarity correctly in the initial type of cognition level.
\end{abstract}

Keywords: Cognition; Metacognition; Epistemic Cognition; Problem Solving; Mathematics

\section{Introduction}

Problem solving skill is one of the most important skills in facing 21 st century. There are some strategies that must be used to compete in this century, namely communication, collaboration, critical thinking, and problem solving, and creativity and innovation. Solving problem is one of the strategies which used in this research. Students need to be able to solve real problems related to reasoning, explanation, arguments, or mathematics skills, because they are expected to contribute to society in the future (OECD, 2010). Problem solving interventions can also help students to develop a set of structured, semi-structured, and heuristic approaches when tackling new problem situations, (Barak, 2013). According to Tarigan, in solving mathematics problems, process and strategy should be prioritized instead of results (Tarigan, 2012).

Referring the above phenomena, contextual issues must be given to students in order to meet the demands of 21 st century. The use of contextual problems actually started from the philosophy of Hans Freudenthal "Mathematics as human activity" (Lange, 1987; Gravemeijer, 1994; Zulkardi, 2002; Wijaya, 2012). That sentence has a meaning that mathematics was very close to human life. Mathematics exists because of human activity so that every human activity can not be released with mathematics. Therefore, 
the questions on the PISA mathematics are based on real world problems and hone student thinking in solving the problem (Stacey, 2012).

The contextual problem in this study is solving mathematics problem in the form of story. The type of problem solving questions are: (1) interesting and challenging for students, (2) requiring critical analysis and observation skills, (3) providing opportunities for discussion and interaction in solving them, (4) understanding mathematics concepts and mathematics application skills, (5) directing to the mathematics principle, (6) allowing the variations in answers and time (Krulik \& Rudnick, 1993).

Students' skill in solving mathematics problems is various. It gives an impact to students' cognitive levels (Setianingrum, Sujadi, \& Pramudya, 2017). Cognitive levels of students in solving mathematics problems are the levels of individual abilities in solving mathematics problems. The definition of cognitive levels in this article refers to Kitchener's theory which states that at the first level of cognition (level 1), individuals enter into cognitive tasks such as computing, memorizing, reading, perceiving, acquiring language, etc. These are the pre-monitored cognitive processes on which knowledge of the world is built. The second level (level 2), metacognition as defined as the processes wich are invoked to monitor cognitive progress when an individual is engaged in level 1 cognitive tasks or goals such as the list above. The third level (level 3) epistemic cognition is characterized as the processes an individual invoke to monitor the epistemic nature of problems and the truth value of alternative solutions (Kitchener, 1983).

The author combines the definition of cognitive levels from Kitchener above with the opinion of Anderson \& Karthwohl. According to Anderson \& Karthwohl (2001), the dimension of knowledge is divided into four categories, including; first, factual knowledge is knowledge about the basic elements that students must know to learn a discipline or to solve problems in the discipline. Second, conceptual knowledge is the knowledge of the relationship between basic elements in a large structure that enables the elements to function together. Third, procedural knowledge is knowledge about how to do things, practice research methods, and criteria for using skills, algorithms, techniques, and methods. Fourth, metacognitive knowledge is knowledge about cognitive in general and knowledge of self-cognition.In this study, cognitive level is described in accordance with the combination of Kitchener, Anderson, and Karthwohl as follows; first, cognition level consists of factual knowledge; conceptual knowledge; and procedural knowledge. For factual knowledge, it includes terminology knowledge and specific element detail knowledge. Conceptual knowledge consists of classification and category knowledge, principle knowledge and generalization, theory, model and structural knowledge. Procedural knowledge includes expertise knowledge and algorithms, knowledge of techniques and specific methods of a subject, and knowledge of criteria to determine the use of appropriate procedures; second, metacognition level consists of strategic and cognitive tasks knowledge; third, the epistemic cognition level includes knowing about the limits of knowledge; belief in knowledge; and criteria for knowing a thing (Yumniyati, 2018).

Some definitions related to cognition, metacognition, and epistemic cognition that reinforces theories from Kitchener, Anderson, and Karthwohl are: (1) Berger \& Luckmann (2005), state that cognition is an individual's belief about something that is obtained from the process of thinking about something. The process is acquiring knowledge and manipulating knowledge through activities of remembering, analyzing, judging, reasoning, and imagining; (2) Flavell (1976) states that metacognition is knowledge and cognition about cognitive objects; (3) Margaret W. Matlin in Desmita (2011) states that metacognition is "knowledge and awareness of cognitive processes or our thoughts about thinking". Meanwhile, epistemic cognition is the way how individuals understand the concept of certainty, simplicity, source, and justification of knowledge (Mason, Boldrin, \& Ariasi, 2009). This case shows that epistemic cognition is the most perfect level compared to the level of cognition and the level of metacognition. 
The researchers have already conducted research related to cognitive levels in highly capable subjects. High-capable subjects are able to produce good results at each level. Subjects are able to work on the set of questions coherently and correctly on three methods at the same time, but the subjects are still unable to distinguish between inequality and dissimilarity. It indicates that the subject is still weak on factual knowledge. At the epistemic cognition level, subjects have not been able to show the criteria of this level properly. Therefore, researchers want to examine further research related to low-ability subjects in solving a set of questions about three-variable linear equation system material.

\section{Methodology}

The researchers collect data through task-based interviews from two low-ability students with the initials Subject E and Subject F. The two subjects are tenth grade of State Senior High Schools in Pati. The method is a qualitative method. Supporting instruments are in the form of mathematics problems about three-variable linear equation system and interviews. Time triangulation is technique for checking the validity of data. Time triangulation is comparing and re-examining the degree of trust in information obtained through different times (Moleong, 2007). The data analysis technique is Miles and Huberman techniques, namely data reduction, data presentation, and conclusions or verification. Data analysis is carried out by analyzing the results of task-based interviews about three-variable linear equation system.

The indicators of each level refer to the combination of Kitchener, Anderson \& Karthwohl. Indicator for cognition level is; first, factual knowledge, including: (1) students are able to write down a replacement symbol of a number which the value is not yet clearly known. Usually, it is symbolized by lowercase letters $\mathrm{a}, \mathrm{b}, \mathrm{c}, \ldots \mathrm{z},(2)$ students are able to differentiate the symbol of equations and inequality correctly, such as $=, \leq, \geq$, etc, (3) students are able to distinguish equation, inequality, similarity, and dissimilarity correctly, (4) students are able to identify variables, coefficients, and constants, (5) students are able to distinguish between linear and non-linear, (6) students explain correctly the known information contained in the set of tasks by identifying the information on the set of tasks whether it is enough to answer or not), (7) students are capable to write down the asked information in the set of tasks (by understanding the materials and steps to answer the given set of tasks), (8) students are able to write down other information (hidden information) needed to answer the set of tasks. Second, conceptual knowledge, including: (1) students are able to classify linear equation and systems of linear equation, (2) students are able to explain correctly regarding the criteria (characteristics) of an equation which can be considered as a system of equation, (3) students are capable to write down the general form of linear equation, (4) students are capable to describe a system of linear equations of three variables (by categorizing between linear equation of three variables and not linear equations of three variables), (5) students are able to write down the general form of a three-variable linear equation system. Third, procedural knowledge including: (1) students are able to mention various methods (substitution method, elimination method, and combination method) used to solve problem of three-variable linear equation system, (2) students are able to explain and write down the operation technique of a number correctly, including addition, subtraction, multiplication, and division, (3) students are able to explain and write down substitution, and elimination techniques, etc, (4) students are capable to choose the most appropriate method to solve the problem of three-variable linear equation system, and the subjects are also able to provide a reason scientifically (Yumniyati, 2018).

Indicator for metacognition level is divided into: first, strategic knowledge which means knowledge of learning strategies in solving problems; second, knowledge of cognitive tasks that are interpreted by when and how the strategies in each method are applied (Yumniyati, 2018).Meanwhile, the indicators of epistemic cognition level are; first, knowing about the limits of knowledge, including; (1) understand the known and unknown information, (2) understand the ability to work on the problem; second, confidence in knowledge, including; confidence in working on a question; third, criteria to know 
which are interpreted by knowing the strategies and solutions to solve the problems (by explaining the characteristics of the right questions in each method)(Yumniyati, 2018).

\section{Findings and Discussion}

Based on the first and second task-based interview, then it is analyzed and compared to find valid data related to cognitive level of subject $\mathrm{E}$ and subject $\mathrm{F}$ in solving mathematics problems.

\section{a. Cognition Level}

In accordance with the indicators described earlier, the level of cognition can be analyzed based on factual, conceptual, and procedural knowledge (Anderson and Karthwohl, 2001). The knowledge will be explained in table 1 , table 2 , and table 3 .

Table 1. Factual Knowledge Type of Cognition Level

\begin{tabular}{|c|c|}
\hline Data Valid of Subject E & Data Valid of Subject F \\
\hline $\begin{array}{l}\text { 1. She is able to write down correctly a } \\
\text { substitute symbol of a number which } \\
\text { the value is not yet clearly known. }\end{array}$ & $\begin{array}{l}\text { 1. She is able to write down correctly a } \\
\text { substitute symbol of a number which } \\
\text { the value is not yet clearly known. }\end{array}$ \\
\hline $\begin{array}{l}\text { 2. She understands the differences } \\
\text { between symbols of equality and } \\
\text { inequality. }\end{array}$ & $\begin{array}{l}\text { 2. She understands the differences } \\
\text { between symbols of equality and } \\
\text { inequality. }\end{array}$ \\
\hline $\begin{array}{l}\text { 3. She is unable to explain equation, } \\
\text { inequality, similarity, and } \\
\text { dissimilarity correctly. }\end{array}$ & $\begin{array}{l}\text { 3. She is unable to explain equation, } \\
\text { inequality, similarity, and } \\
\text { dissimilarity correctly. }\end{array}$ \\
\hline $\begin{array}{l}\text { 4. She is able to identify variables, } \\
\text { coefficients, and constants correctly. }\end{array}$ & $\begin{array}{l}\text { 4. She is able to identify variables, } \\
\text { coefficients, and constants correctly. }\end{array}$ \\
\hline $\begin{array}{l}\text { 5. She is unable to differentiate } \\
\text { between linear and non-linear } \\
\text { correctly. }\end{array}$ & $\begin{array}{l}\text { 5. She is unable to differentiate } \\
\text { between linear and non-linear } \\
\text { correctly. }\end{array}$ \\
\hline $\begin{array}{l}\text { 6. She is able to explain the known } \\
\text { information in the questions } \\
\text { correctly. }\end{array}$ & $\begin{array}{l}\text { 6. She is able to explain the known } \\
\text { information in the questions } \\
\text { correctly. }\end{array}$ \\
\hline $\begin{array}{l}\text { 7. She understands the asked } \\
\text { information, materials, and methods } \\
\text { to solve the problems. }\end{array}$ & $\begin{array}{l}\text { 7. She understands the asked } \\
\text { information, materials, and methods } \\
\text { to solve the problems. }\end{array}$ \\
\hline $\begin{array}{l}\text { 8. She is unable to look for hidden } \\
\text { information in the questions. }\end{array}$ & $\begin{array}{l}\text { 8. She is unable to look for hidden } \\
\text { information in the questions. }\end{array}$ \\
\hline
\end{tabular}

Based on Table 1, in the terminology sub type of factual knowledge type, both subjects are able to write down a substitute symbol of a number, distinguish equality and inequality symbol, and identify variables, coefficients, and constants. However, both subjects are unable to define equation, inequality, similarity, and dissimilarity correctly. They are also unable to differentiate between linear and non-linear correctly. Moreover, in the detail element of specific object sub type, they explain the known and the asked information in the set of questions. However, they are unable to write down and look for hidden information within the questions.

Generally, every subject still has limited basic knowledge of each material, they are able to answer the question given by the teacher, but they do not master the material completely. Even though the presence of basic knowledge of each learning material is important, not all students realize it. Anderson \& 
Karthwohl (2001) point out that basic knowledge such as terminology knowledge is very specific and beneficial, so the experts expect that the students are able to promote their knowledge more than they have known.

Table 2. Conceptual Knowledge Type of Cognition Level

\begin{tabular}{lll}
\hline Data Valid of Subject E & Data Valid of Subject F \\
\hline $\begin{array}{l}\text { She is unable to classify linear } \\
\text { equation and linear equation } \\
\text { system. }\end{array}$ & $\begin{array}{l}\text { 1. } \begin{array}{l}\text { She is unable to classify linear } \\
\text { equation and linear equation } \\
\text { system. }\end{array} \\
\text { 2. She is unable to explain correctly } \\
\text { the process of equation become } \\
\text { equation system, and he is unable } \\
\text { to write down the general form of }\end{array}$ & $\begin{array}{l}\text { She unable to explain correctly } \\
\text { the process of equation become } \\
\text { equation system, and he is unable } \\
\text { to write down the general form of } \\
\text { equation and equation system. }\end{array}$ \\
$\begin{array}{l}\text { equation and equation system. } \\
\text { She is able to differentiate correctly } \\
\text { between three-variable linear } \\
\text { equation system and not, however } \\
\text { he is unable to write down general } \\
\text { form of three-variable linear }\end{array}$ & $\begin{array}{l}\text { She is able to differentiate } \\
\text { eqrrectly between three-variable } \\
\text { equation system. }\end{array}$ \\
$\begin{array}{l}\text { linear equation system and not, } \\
\text { however he is unable to write } \\
\text { down general form of three- } \\
\text { variable linear equation system. }\end{array}$
\end{tabular}

Based on Table 2, in the conceptual knowledge, both subject are able to differentiate correctly between three-variable linear equation systems and not, but they are unable to classify and write down the general form of linear equation system. Both of them give the general form example of equation or linear equation system, but it is not the general form.

Table 3. Procedural Knowledge Type of Cognition Level

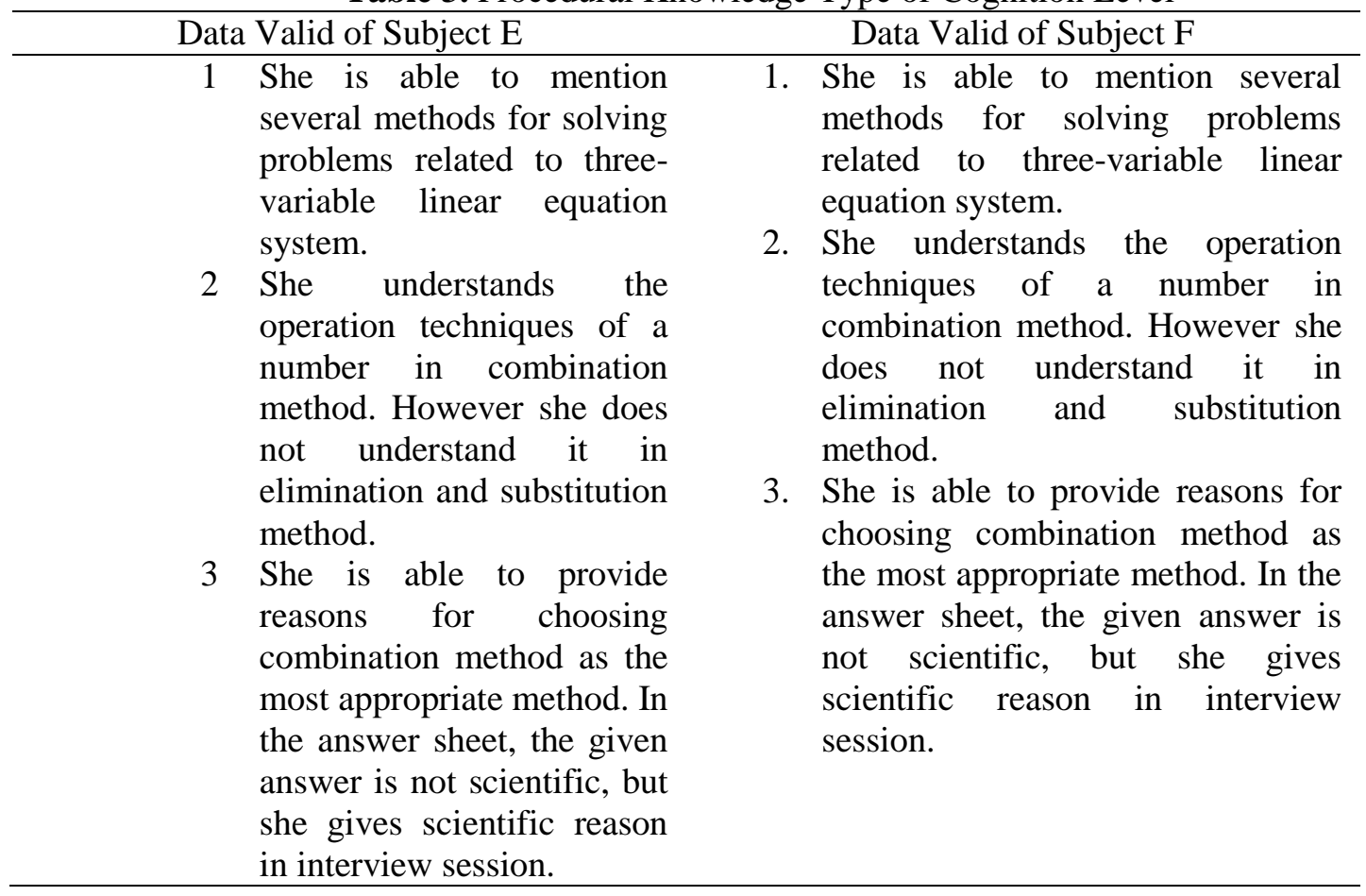


According to Table 3, it can be concluded that both subjects are able to mention various methods to solve problems of three-variable linear equation system, understands the operation techniques of a number in combination method, but they do not understand it in elimination and substitution method. They are also able to choose combination method as the most appropriate method.

\section{b. Metacognition Level}

In this study, metacognition level is analyzed based on two knowledge, namely; strategic knowledge, and knowledge about cognitive tasks (Anderson and Karthwohl, 2001). The explanation is found in Table 4.

Table 4. Metacognition Level

\begin{tabular}{|c|c|}
\hline Data Valid of Subject E & Data Valid of Subject F \\
\hline $\begin{array}{l}\text { 1. Strategy used in choosing } \\
\text { combination method is repetition } \\
\text { strategy. }\end{array}$ & $\begin{array}{l}\text { 1. Strategy used in choosing } \\
\text { combination method is repetition } \\
\text { strategy. }\end{array}$ \\
\hline $\begin{array}{l}\text { 2. She is able to provide overview of } \\
\text { initial steps in solving problem } \\
\text { using three methods. }\end{array}$ & $\begin{array}{l}\text { 2. She is able to provide overview of } \\
\text { initial steps in solving problem } \\
\text { using three methods. }\end{array}$ \\
\hline
\end{tabular}

Based on Table 4, in the metacognition level, subject $\mathrm{E}$ and subject $\mathrm{F}$ are able to provide concrete reasons or considerations when choosing a combination method to solve the problem as the most appropriate method, because the two subjects have repetition learning strategy, which is used to repeat the combination method to solve linear equation system. In this level, they are also able to provide overview of initial steps in solving problem using three methods.

\section{c. Epistemic Cognition Level}

The epistemic cognition level is described based on the three indicators that have been explained previously, namely; knowing about the limits of knowledge; confidence in knowledge; and criteria to know (Kitchener, 1983). The epistemic cognition level of subject $\mathrm{E}$ and subject $\mathrm{F}$ is explained in Table 5 below.

Table 5. Epistemic Cognition Level

\begin{tabular}{lll}
\hline \multicolumn{1}{c}{ Data Valid of Subject E } & Data Valid of Subject F \\
\hline 1 & $\begin{array}{l}\text { She is able to explain the } \\
\text { weaknesses of the methods. }\end{array}$ & $\begin{array}{l}\text { 1. She is able to explain the } \\
\text { weaknesses of the methods. }\end{array}$ \\
2 & $\begin{array}{l}\text { She does not master yet the way } \\
\text { to overcome the weaknesses. }\end{array}$ & $\begin{array}{l}\text { She does not master yet the } \\
\text { way to overcome the } \\
\text { whe is unable to give overview } \\
\text { of question for each method. }\end{array}$ \\
\end{tabular}

Based on Table 5 which explains epistemic cognition level, subject $\mathrm{E}$ and subject $\mathrm{F}$ understand the weaknesses or weaknesses related to the three methods used to solve the problem, but both subjects have not been able to overcome weaknesses in the method that is considered weak, namely elimination and substitution method. Both subjects have not been able to provide scientific reasons to overcome these 
difficulties. Both subjects also have not been able to provide a description of the questions for each method that is used properly and correctly.

The subjects are lack to solve their problems because most of them have never been taught about self-assessment. Black and William (2004) believe that self-assessment is an essential part of learning, but that students are not skilled in self-assessing and that it takes time to develop this skill. According to Herman (2001), self-assessment is very important because students are the best evaluator for their own work or feeling. When the students learn to assess their own work, they will be more responsible for their learning activity that they do.

\section{Conclusion}

Based on the results of data analysis and validity of the research data, it can be concluded that cognitive level of students with low mathematics abilities in solving problems of three-variable linear equation system are; (1) at cognition level, subjects master factual knowledge well, but they still have difficulty in defining equations, inequalities, similarities, and dissimilarity; they have not been able to distinguish between linear and non-linear correctly, and they have not been able to write or search for hidden information in the question. (2) at conceptual knowledge, both subjects are able to distinguish three-variable linear equation or not, but they are unable to classify and write down the general form of linear equation system. Both of them give the general form example of equation or linear equation system, but it is not the general form. (3) at procedural knowledge, both subjects are only able to understand operation techniques of a number in combination method, whereas both subjects are not able to provide the right answer for elimination and substitution method.

At metacognition level, both subjects are able to provide concrete reasons or considerations when choosing a combination method as the most appropriate method to solve the given problems and they are able to write each strategy on each method.At epistemic cognition level, both subjects understand the weaknesses that exist in him, but they have not been able to provide scientific reasons to overcome these difficulties, and they have not been able to provide a description of the questions for each method that is used properly and correctly.

\section{Suggestion}

Based on the results and discussion of this study, there are some suggestions for further research including; in teaching a new material to students, a teacher should convey the material in detail so that students are able to capture the material comprehensively; students should have a high curiosity to learn all materials provided by teacher, so that learning objectives can be achieved through the awareness of each student and teacher.

\section{References}

Anderson, L., \& Karthwohl, D. (2001). A Taxonomy for Learning Teaching and Assesing. New York: Longman.

Barak, M. (2013). Impacts of learning inventive problem solving principles. Students' transition from systematic to heuristic problem solving. Instructional Science, 41, 657-679.

Black, P., Harrison, C., Marshall, L. B., \& William, D. (2004). Working Inside The Black Box: Assessment for Learning in The Classroom. Phi Delta Kappan. 8(1), 8-21. 
Berger, P., \& Luckmann, T. (2005). Interpersonal Intellegence. Jakarta: Amara Books.

Desmita. (2011). Psikologi Perkembangan Peserta Didik. Bandung: PT Remaja Rosdakarya.

Flavell, J. (1976). Metacognition Aspects of Problem Solving: in Resnick, The Nature of Intelligence. Erlabaum: Hillsdale.

Gravemeijer. K. (1994). Developing Realistic Mathematics Education. Freudenthal Institute. Utrecht.

Herman, T. (2001). Asesmen Portofolio dalam Pembelajaran Matematika. Prosiding Seminar Nasional Matematika Universitas Gajah Mada . Yogyakarta 14 Juli 2001

Kitchener, K. S. (1983). Cognition, Metacognition, and Epistemic Cognition: A three-Level Model of Cognitive Processing. Hum. Dev. 26, 222-232.

Krulik, S., \& Rudnick, J. (1993). Reasoning and Problem Solving: A Handbook for Elementary School Teacher. Boston: Allyn \& Bacon.

Lange Jzn, J. de. (1987). Mathematics, Insight and Meaning. Utrecht: OW\&OC.

Mason, L., Boldrin, A., \& Ariasi, N. (2009). Epistemic metacognition in context: evaluating and learning online information. Metacognition and Learning. 5, 67-90.

Moleong, L. J. (2007). Metodologi Penelitian Kualitatif. Bandung: PT Remaja Rosdakarya.

OECD. (2010). PISA 2012 Mathematical Framework. Paris: OECD.

Setianingrum, A., Sujadi, I., \& Pramudya, I. (2017). The Process of Reflective Thinking in Mathematics Problem Solving Review from Cognitive Style. International Conferens Mathematics and Science Education (p. 358). Bandung: Universitas Pedidikan Indonesia.

Stacey, K. (2012). The International Assessment of Mathematical Literacy: PISA 2012 Framework and Items (Eds). Proceedings of The 12th International Congress on Mathematical Education, 756772.

Tarigan, D, E. (2012). Analisis Kemampuan Pemecahan Masalah Matematika Berdasarkan LangkahLangkah Polya pada Materi Sistem Persamaan Linear Dua Variabel Bagi Siswa Kelas VIII SMP Negeri 9 Surakarta Ditinjau Dari Kemampuan Penalaran Siswa. Tesis. Surakarta: Universitas Sebelas Maret.

Wijaya, A. (2012). Pendidikan Matematika Realistik. Yogyakarta: Graha Ilmu

Yumniyati, K. (2018). Level-level Kognitif Siswa Kelas X SMA Negeri 1 Juwana Pati dalam Pemecahan Masalah Matematika pada Materi Sistem Persamaan Linear Tiga Variabel. Tesis. Surakarta: Universitas Sebelas Maret.

Zulkardi. (2002). Development a Learning Environment on Realistic Mathematics Education for Indonesian Student Teachers. Dissertation. University of Twente, Enschede. The Netherland. 


\section{Copyrights}

Copyright for this article is retained by the author(s), with first publication rights granted to the journal.

This is an open-access article distributed under the terms and conditions of the Creative Commons Attribution license (http://creativecommons.org/licenses/by/4.0/). 